\title{
Implications of Solving Criminal Matters with Restorative Justice Approach
}

\author{
Edy Herwiyanto 1)*, Abdul Rachmad Budiono 2), Bambang Sugiri 3), Prija Djatmika 4). \\ 1) Doctorate Candidate of Law Faculty, Brawijaya University, Malang, Indonesia. \\ 2) Professor of Law Faculty, Brawijaya University, Malang, Indonesia. \\ 3) Postgraduate Program of Law Faculty, Brawijaya University, Malang, Indonesia. \\ 4) Postgraduate Program of Law Faculty, Brawijaya University, Malang, Indonesia. \\ E-mail of the corresponding author : edy.herwiyanto@gmail.com
}

\begin{abstract}
:
The essence of the implementation of restorative justice is an effort to achieve justice and the implementation of law enforcement without setting aside one another, so as to create a sense of justice and create legal certainty in the settlement of criminal acts by prioritizing the principles of benefit and legal certainty. Settlements are carried out outside the proper channels with the aim of protecting the interests of both parties in providing a win-win solution, namely victims of criminal acts and perpetrators of criminal acts. The results of legal research using a conceptual and statutory approach show that judicial institutions in Indonesia have not implemented or implemented the concept of restorative justice as a whole, this is the problem in the research. This can be proven by the fact that if viewed from the series of developments in the concept of restorative justice, restorative implementation in Indonesia has not been implemented or is categorized as restorative which implies that it cannot be applied or can only be partially applied to this justice approach system in Indonesia, one of which can in restorative (can use the concept of restorative justice) is on the settlement of minor crimes.
\end{abstract}

Keywords : Implication, Criminal, Restorative Justice

DOI: $10.7176 / \mathrm{JLPG} / 110-10$

Publication date:June $30^{\text {th }} 2021$

\section{INTRODUCTION}

The settlement of a case can basically use two methods, namely the settlement by litigation and non-litigation. In reality, if a problem occurs, especially those related to criminal law (criminal cases), the problem solving model is always carried out using the litigation channel. In practice, the settlement of cases using the litigation pathway does not always work as expected because the settlement of cases using the litigation route in the traditional criminal justice system currently creates problems such as: a. The pattern of punishment that is still retaliatory in nature, b. Causing an accumulation of cases, c. Pay no attention to the rights of victims, $d$. Not in accordance with simple judicial principles; e. The process is long, complicated and expensive, f. The settlement is legistic and rigid, g. Not recovering the effects of evil, h. Inadequate conditions of prisons, i. Does not reflect justice for society. In essence, law was created to provide a sense of justice and benefits to humans. The current development of law has given birth to an approach with a new concept, namely the concept of restorative justice. The concept of restorative justice is expected to be an answer and to overcome various problems in the traditional criminal justice system. The current phenomenon when a criminal act occurs, the public tends to use court channels which conceptually and theoretically will create justice, but in reality this is not an easy thing to achieve. It needs to be realized that the results to be achieved from the process of settlement of cases using the judiciary are win-lose solution, with this characteristic, there will be winners and losers. The settlement of a case using the court will cause an unpleasant feeling, a sense of revenge, feeling dissatisfied with the outcome of the decision, and even arousing a sense of revenge against the perpetrator of the crime or vice versa. This will be a principle that is embedded in the losing party and will seek justice to a higher level of justice, either making an appeal or making an appeal for parties who are not satisfied with the high court decision. The above phenomenon causes the flow of cases flowing through the courts, both at the District Court, High Court and at the Supreme Court level to go very fast, causing a buildup of cases. According to Joni Emirzon in his book entitled Alternative Out of Court Dispute Resolution, this is categorized as one of the weaknesses of a litigation institution that cannot be avoided even though it has become a provision. An expert named Satjipto Raharjo gave a similar statement that the settlement of cases through the judicial system which resulted in a court verdict constitutes a slow-moving law enforcement. This is because law enforcement takes a long distance, through various levels ranging from the Police, Attorney General's Office, District Courts, High Courts even to the Supreme Court. In the end, it resulted in a large number of cases in court. In addition, justice that is expected through formal means does not necessarily reflect a sense of justice, is expensive, prolonged, tiring and does not solve the problem and what is even worse is that it is full of corruption, collusion and nepotism practices. According to Bambang Sutiyoso, who gave his statement in his book entitled "Business Dispute Resolution, 
Solutions and Anticipation for Business Enthusiasts in Facing Current and Future Disputes" stated that currently dispute resolution through courts has received sharp criticism, both from practitioners and legal theorists. The role and function of the judiciary is currently considered too heavy (overloaded), slow and a waste of time (waste of time), expensive (very expensive) and less responsive to public interests, or considered too formalistic (formalistic) and too technical ( technically), especially the existence of a "judicial mafia" which seems to indicate the judge's decision can be bought. Responding to the various problems above, in recent developments an alternative has emerged, namely implementing the concept of restorative justice. The concept of restorative justice is a popular alternative in various parts of the world for handling illegal acts (against the law in the formal sense) because it offers a comprehensive and effective solution. Restorative justice aims to empower victims, perpetrators, families and communities to correct an illegal act by using awareness and conviction as a basis for improving social life.

The concept of justice that prioritizes restoration or what is commonly called restorative justice, which is a new approach to solving a criminal case. In contrast to the existing system (traditional criminal system), the approach or concept of restorative justice or restorative justice focuses more on the direct participation of perpetrators, victims and the community in the criminal case settlement process. Therefore, this approach is popularly known as the non-state justice system in which the role of the State in solving criminal cases is small or even nonexistent. However, the presence of the approach or concept of restorative justice or restorative justice is filled with various questions both theoretically and practically. The main problem for enforcing or implementing the restorative justice approach or concept in a legal system in general and in the criminal justice system in particular lies in the settlement mechanism offered by the restorative justice approach or concept, in contrast to the settlement mechanism offered by the current criminal justice system so that it is still difficult to accept. This is because the mechanisms offered by the restorative justice approach or concept prioritizes the concept of peace, the concept of mediation, the concept of reconciliation in which perpetrators, victims, law enforcement officials and the wider community participate directly in solving criminal cases, of course, is inversely proportional or contradicting. with a traditional criminal justice system that has been in place for a long time and is in effect today. This is motivated by the focus of attention and views on a criminal act and the justice achieved for a criminal case settlement.

\section{LEGAL MATERIALS AND METHODS}

Legal research recognizes several approaches, to facilitate the attainment of truths that are the focus of research. According to Johny Ibrahim "divides into 7 (seven) normative legal research approaches, namely:

1) Statute approach

2) Conceptual approach

3) Analytical approach

4) Comparative approach

5) Historical approach

6) Philosophy approach

7) Cases approach

Johny Ibrahim provides assertion that the approaches in normative legal research include: the approach of legislation, concepts and comparisons. Methods of approach in legal research are often also seen in the perspective of legal science. As a science then logic, understanding, values, morals, justice, ideas, ideals into a set of domains that must get their own attention. The more complete the affirmation of the domain in the study of legal science deepens and thorough the results of the study conducted.

As noted above, that in the tradition of legal research (normative), focuses attention on the study of primary, secondary and tertiary legal materials. In this study primary, secondary and tertiary legal materials, obtained by way of discussion, study documentation, and literature study.

\section{III.RESULT AND DISCUSSION}

Problems in the Implementation of Restorative Justice The view of the meaning of a criminal act and punishment adopted in the traditional criminal justice system today is "is a violation of the state define by lawbreaking and guilty" which is translated into Indonesian, which means state violation is defined as a violation of the law and guilt. While justice in the traditional criminal justice system is understood as proof of indictment and conviction of criminals by the state as the holder of sovereignty in imposing crimes, this in the end has an impact on the condition that the interests of victims and society are not represented in a system that is related to one another. A different concept of restorative justice was also put forward by Tonny Marshal and Howard Zehr who stated the following: 1. Tonny Marshal Restorative justice is a process whereby all the parties with a stake in a particular offense come together to resolve collectively how to deal with the aftermath of the offense and its implications for the future. (Restorative justice as a process that involves all parties who have an interest in a particular 
violation problem to come together to resolve collectively how to address and resolve the consequences of violations and their implications for the future). 2. Howard Zehr Viewed through a restorative lens, crime is a violation of people and relationships. It creates obligations to make things right. Justice involves the victim, the offender, and the community in a search for solutions which promote repair, reconciliation, and reassurance. (Seen through the lens of restorative justice, crime is a violation of people and this relationship creates an obligation to do the right thing. Justice involves victims, perpetrators and society in finding solutions that promote remedy, reconciliation and assurance). Muladi, in his book entitled Kapita Selekta on the Criminal Justice System, states that the criminal justice system is a network of courts that uses material criminal law, formal criminal law and criminal implementation law. However, this institution must be seen in a social context. The nature that is too formal if it is based only for the sake of legal certainty will bring disaster in the form of injustice. The criminal justice system in Indonesia is strictly regulated in the Criminal Procedure Code (KUHAP) or Law Number 8 Year 1981. It is said that because of Law No. 8 of 1981 or the Criminal Procedure Code (KUHAP) is actually synonymous with criminal law enforcement, which is a system of powers or authorities given to the state in enforcing criminal law, namely the police, prosecutors, judges and prisons.

The definition of a criminal justice system is also called a law enforcement system because it contains an understanding that basically what these institutions do is a concrete effort to enforce abstract legal rules. In relation to the integrated criminal justice system, Muladi explained that the meaning of an integrated criminal justice system is a synchronization or greed and harmony, which can be distinguished in several ways, namely: 1. Structural synchronization (structural syncronization) is the randomness or harmony in the framework of relations between law enforcement agencies; 2. Substantial synchronization (substantial syncronization) is the vertical and horizontal alignment or alignment in relation to positive law; 3. Cultural synchronization (cultural syncronization) is harmony in living the views, attitudes and philosophies that as a whole underlie the running of the criminal justice system. Based on the statement of opinion from Muladi above, that between the sub-systems contained in the criminal justice system must have the same structural, substantial and cultural (structural, substantial and cultural in applying the concept or restorative justice approach). In short, if one of the subsystems contained in the criminal justice system does not implement the concept or approach of restorative justice, the concept or approach of restorative justice will not work well. Braithwaite argues that Indonesia is a nation with wonderful resources of intracultural restorative justice. Traditions of musayawarah (musyawarah) decision by friendly cooperation and deliberation-traverse to the archipelago. Adat law at the same time allows for diversity to the point of local criminal laws being written to complement universal national laws. Based on Braithwaite's opinion, it is clear that the practice of solving problems with the approach or concept of restorative justice (restorative justice) does exist in the culture or culture of the Indonesian nation as has been done in West Sumatra, even though this is done by certain elites from society. Braithwaite believes that by providing a little training, it is not only the elite that can facilitate problem-solving practices with a restorative justice approach or concept but more people, however, efforts to democratize restorative practices against Asians can potentially lead to a mistake.

Thus, considering that the Supreme Court (MA) is a state institution that exercises judicial power and as the top of the judiciary, it should be, if the Supreme Court (MA) adopts or adopts and implements the approach or concept of restorative justice (restorative justice). In this case, the authors highlight the Supreme Court (MA) because the Supreme Court (MA) is the peak so that if the Supreme Court (MA) adopts or adheres to and applies the concept of restorative justice (restorative justice) then the judiciary under it will adopt, adopt and apply the concept. restorative justice. In this way, it is hoped that the concept of restorative justice can be applied in the entire judicial system in Indonesia from the District Courts to the High Courts and the Supreme Court itself. In addition, the Law on Judicial Power, namely the Law of the Republic of Indonesia Number 48 of 2009 concerning Judicial Power, specifically Article 5 clearly states that judges are obliged to explore the values that live in society (the living law or local wisdom). Thus, in essence, judges must or must apply the approach or concept of restorative justice in resolving cases because the approach or concept of restorative justice is in accordance with the spirit of the Indonesian nation, namely Pancasila, in accordance with the values of customary law and accordingly. with religious values. It should also be noted that the concept of restorative justice cannot only be applied to the Supreme Court (MA). In the criminal justice process in general and in the criminal justice process in Indonesia in particular, there are several stages or processes that must be passed for justice seekers at the level of investigation, investigation, prosecution, examination in court to the stage of making a judge's decision. Even at the stage where justice seekers make legal remedies (both ordinary remedies and extraordinary remedies). Thus, researchers consider that the adoption and application of the concept of restorative justice should be carried out at various levels or judicial processes as stated above. Based on the explanation above, the author also concludes that the concept or approach of restorative justice must be implemented in an integrated manner. This is important considering that if one of these components does not 
apply the concept or approach of restorative justice, then a restorative decision may not be implemented. For example, the police and the prosecutor's office have embraced the concept of restorative justice but judges still adhere to a legistic mindset, in cases like this the judge will issue a very normative decision so that even prisons cannot apply the concept of restorative justice.

Therefore, the approach or concept of restorative justice must be carried out in an integrated manner between one component and another. Conversely, if one component does not carry out the restorative justice approach or concept, the restorative justice approach or concept itself will not be properly realized. The criminal law system in Indonesia implies that the implementation of crime is essentially independent of a person's will. The provisions of the criminal law are still violated, despite the consent of the aggrieved party. Of course this is different from the system in civil law. Legal science recognizes that there is a separation between public law and private law. However, in certain relationships, there are elements that contain both public and private elements. In essence, the law regulates human behavior in social life, so the interests of society are always a factor in the making of laws. However, in certain relationships the law focuses on the interests of one human being, while in other relationships it focuses on the public interest. Public law, in this case crime is very different from civil law. In criminal cases, all problems that arise will be submitted to the State to solve them. Although in criminal procedural law theory, the delivery of settlement to the State varies. Some have to be reported, some have to be complained. One of the phenomena that needs to be observed is the peaceful effort made when a criminal act is suspected. Peace efforts made out of court when a criminal act is suspected, such as in a civil case, is only an underhand settlement. Peace efforts carried out outside the court can be exemplified, such as peace between the victim and the perpetrator of the crime of theft (crime). For civil cases, peace efforts are legitimate matters with the principles and regulations related to civilization. However, for criminal cases, peace efforts are something that should be questioned. That question arises because of a provision that "there is no peace in crime" and "achieving peace does not eliminate the existing criminal elements". Many petty criminal cases can be processed on the basis of fast, low cost, and simple trial. For example, a person who steals a banana because he is hungry, while the banana owner can forgive, the ethical consequences do not need to be decided in court, but rather through penal mediation. Responding to this phenomenon, according to Suteki, often some people understand law as merely a set of positive legal rules that are deprived of their philosophical and sociological understanding. Such understanding describes the law as not complete, but only as a fragment or skeleton, namely legislation. This encourages the emergence of the opinion that if the law has been administered as written in black letter law, it will be as if the job of seeking justice has been completed. As a result, there have been many cases that reflect the condition that substantial justice has been alienated from the law. The law is not grounded, it even injures the sense of justice in society. Legal handling of criminal acts in Indonesia is like the power of a spider web. It is only able to ensnare small crimes, but unable to touch large crimes. The problem faced by criminal law enforcement in Indonesia is the absence of a legal forum for settling criminal cases through mediation. The legal doctrine that still applies is that criminal cases cannot be mediated. The criminal justice process is a common sense laboratory because it tests the truth of legal facts with a legal perspective and a conscience to produce truth and justice for both perpetrators and victims. With this in mind, it is necessary to think about solving criminal cases through penal mediation as an effort to resolve the conflict as a whole so that the litigants can resolve problems with their own awareness and prioritize mutual understanding and respect for the rights of victims. It needs to be realized that historically, Indonesian society culture has upheld the consensus approach. Development of dispute resolution in Indonesia in accordance with traditional decision-making mechanisms and customary dispute resolution. The cultural reasons for the existence and development of ADR in Indonesia seem to be stronger than the reasons for the inefficient process of handling disputes.

In the criminal justice system, efforts to establish penal mediation are based on ideas related to penal reform ideas and associated with the problem of pragmatism. The background to the ideas of "penal reform" includes the idea of victim protection, the idea of harmonization, the idea of restorative justice, the idea of overcoming rigidity / formality in the prevailing system, the idea of avoiding the negative effects of the criminal justice system and the existing criminal justice system, in particular. in seeking other alternatives to imprisonment (alternative to imprisonment / alter-native to custody). Settlement of criminal cases using a repressive approach as implemented in the criminal justice system in Indonesia in principle has resulted in retributive justice, which is oriented towards retaliation in the form of punishment and imprisonment. In its development, the discourse on the orientation of punishment has emerged which places victims as an important part of achieving the objectives of punishment. In order to achieve this goal, a criminal case settlement system that is oriented to benefit all parties is offered, namely through the concept of restorative justice. Literally, restorative justice can be defined as the restoration of justice for victims and perpetrators of criminal acts. This definition develops after being included in the criminal justice system, so that the meaning becomes a systematic settlement process for criminal acts that emphasizes the recovery of victims and / or society's losses as a result of the perpetrator's actions. In 
this settlement process, it involves victims and perpetrators directly and actively. According to Adam Graycar, Director of the Australian Institute of Criminology, stated that "in practice, restorative justice requires the support of reintegrative shaming theory in resolving conflicts". Graycar explained by citing Braithwaite's opinion regarding the reintegrative shaming theory, that there are two main aspects inherent in the restorative process, namely: 1 . To achieve the success of reintegration, the process must involve the presence and participation of the community for support of perpetrators and victims. 2. A process that requires a feeling of shame (shaming) as a confrontation for wrongdoing between the perpetrator and the victim. The criminal justice process that is restorative justice has the view that realizing justice is not only a matter for the government and criminals, but more than that it must provide justice in a totality that cannot ignore the interests and rights of victims and society. So the essence of restorative justice emphasizes more on recovery efforts and not on punishment. The current criminal system pays little attention to the interests of victims. The concept of restorative justice theory offers answers to important issues in solving criminal cases, namely: 1. Criticism of the criminal justice system which does not provide opportunities especially for victims (criminal justice system that disempowers individuals). 2. Eliminate conflict, especially between the perpetrator and the victim and the community (taking away the conflict from them). 3. The fact that feelings of helplessness experienced as a result of criminal acts must be overcome in order to achieve reparation.

From the formulation of this understanding, it can be seen that the purpose of restorative justice is to realize the recovery of the condition of crime victims, perpetrators and interested people (stakeholders) through a case resolution process that does not only focus on trying and punishing the perpetrators. The purpose of restorative justice is to repair damage, restore the quality of relationships, and facilitate the reintegration of the parties involved and related. The practice of retorative justice emphasizes the perpetrators and victims, so that the resolution does not just stop at punishing the perpetrator, but the attainment of maturity of the parties concerned to strengthen the quality of the relationship for a longer period of time. 2. Criminal Acts That Can Be Solved With a Restorative Justice Approach As public law that prioritizes the public interest, the application of criminal law through the instruments of state power has its legitimacy. In this case, it is not individuals who will act if there is a violation of the law, but the state through its means. Giving priority to the public interest (the community) can be seen through the imposition of criminal sanctions that take precedence when compared to the provision of compensation for violations of the victim's personal interests. By threatening human behavior punishment, it means that the state takes over the responsibility to maintain the stipulated regulations which are no longer left to individuals. In this case, the state has the duty to investigate and prosecute violations of regulations containing criminal threats. In this context, the state is in fact present to prevent the occurrence of "vigilante" acts. However, currently this thought is confronted with the reality of the community's need for a criminal case resolution mechanism which is considered to be more accommodating to the participation and aspirations of victims and perpetrators. The restorative justice approach is present as an alternative mechanism for solving criminal cases which is expected to cover one of the shortcomings in the criminal justice system. Professor Sudarto stated that the special function of criminal law is to protect the legal interests of the act of raping him with penalties that are sharper in nature when compared to the sanctions found in other branches of law. These legal interests can be in the form of individual legal interests (which can be in the form of legal interests over the right to life (life), body, property rights, dignity or good name and morals), legal interests of society or legal interests of the state. Regarding the special function of criminal law, what needs to be paid attention is that not all criminal acts can be resolved using a restorative justice approach because apart from this restorative justice approach can only be applied if there is free consent from the parties, in principle the peculiarities of criminal law when compared to legal Another law lies in the particular suffering in the form of limitation and deprivation of liberty as stated in the criminal sanction for the legal interest that is "raped". In short, considering the importance of protecting such legal interests, such protection must be carried out using special criminal sanctions when compared to other legal instruments. This restorative justice approach model is widely used for crimes committed by children and adolescents or crimes related to certain indigenous offenders (indigineous offenders). Basically, the application of this restorative justice approach is very likely to be applied in various types of criminal acts which are general in nature and are not acts of which the perpetrator and victim cannot be clearly identified, are political in nature and threaten the safety of the community at large.

In addition, it should also be noted that the handling of criminal acts that threaten the right to life (life) and body as well as the honor of decency, it is necessary to consider whether or not the application of a restorative justice approach is necessary given the characteristics of cases and the dangerous nature of criminal acts against society. Meanwhile, for crimes that threaten dignity (good name) and property rights (property), the private nature of this type of crime makes handling of crimes using restorative justice purely applicable. The disadvantage that refers to the interests of individuals allows the model of settlement through deliberation and mediation to become more open. Specifically speaking about the power of the Public Prosecutor to stop prosecution, Article 42 paragraphs 
(2), (3) and (4) of the 2014 Draft Criminal Procedure Code (RKUHAP) has apparently provided space for the Public Prosecutor to stop prosecution on the grounds: 1 . The criminal offense was light in nature; 2 . The criminal act committed is punishable by a maximum imprisonment of 4 (four) years; 3 . The criminal act committed is only punishable by a fine; 4 . The age of the suspect at the time of committing the crime is over 70 (seventy) years; and / or 5. Losses have been replaced. For the last two categories (number 4 and 5) the law requires that the provision only applies to criminal offenses which are punishable by a maximum imprisonment of 5 (five) years. The authority of the Public Prosecutor is also supported by the authority of the Preliminary Examining Judge to decide whether a case is appropriate to proceed to the prosecution stage at the request of the Public Prosecutor as regulated in the provisions of Article 44 paragraph (1) and (2) of the 2014 RKUHAP. Article 153 letter $d$ of the Draft Law The 2015 Criminal Code (RKUHP) also stipulates that one of the reasons for the loss of prosecution authority is the settlement of cases outside the process. As explained in the previous section of this paper, one of the fundamental problems if this restorative justice approach is to be applied is the question of the authority of both the police, prosecutors and judges to apply a restorative justice approach that has not been explicitly regulated by law. By referring to the provisions of the articles in the RKUHP and RKUHAP above, it can be seen that there is room for the end of prosecution of certain cases which are limitedly regulated in law. This authority is granted by law to prosecutors who are also supported by the preliminary examining judge's authority. In addition, the law has also explicitly stated that the settlement of cases outside the criminal justice system is one of the reasons for terminating prosecution. Such an arrangement shows that there are regulatory changes in the Draft regarding the reasons for eliminating prosecution which in this case supports the application of a restorative justice approach. The regulation of the restorative justice approach has also begun to appear in the purposes of punishment and things that must be considered in the punishment regulated by the RKUHP 2015. In the provisions of Article 55 paragraph (1) letters c and d of the 2015 RKUHP, several purposes of punishment are stated, including: 1 . Resolving conflicts arising from criminal acts, restoring balance and creating a sense of peace in society; and 2. Releasing guilt to the convict. Meanwhile, one of the things that must be considered in criminalization (punishment guidelines) as regulated in Article 56 paragraph (1) letter $\mathrm{j}$ of the 2015 RKUHP is forgiveness of the victim and / or his family. Referring to the previous section in this paper which talks about changing perspectives on crime and justice in the criminal justice system and the restorative justice approach, it can be seen that the purpose of punishment as regulated in the RKUHP has included the concept of a restorative justice approach that is oriented towards restoring balance to what it was before it happened. conflict. In addition, forgiveness from the victim or the family is one of the things that must be considered in imposing a sentence. The formulation of these provisions implicitly shows the acceptance of the application of a restorative justice approach which basically can also be used as material for thought to determine the criteria or qualifications for criminal acts that can be resolved using a restorative justice approach.

Settlement of Minor Crime Cases through Penal Mediation in the Perspective of Restorative Justice. Settlement of cases through penal mediation is one of the processes of law enforcement, whereas law enforcement itself is a series of processes to describe fairly abstract values, ideas and ideals which are the objectives of law. Legal objectives or legal ideals contain moral values, such as justice and truth. These values must be able to be realized in real reality. The existence of law is recognized if the moral values contained in the law can be implemented or not. In this regard, it is necessary to conduct a study to find other alternatives that can be developed in the (criminal) law enforcement process towards a more equitable settlement of minor criminal cases. In the opinion of the author, the more equitable settlement of minor criminal cases should be resolved through penal mediation because the harmful effects and losses arising from the crime are also minor. In viewing the settlement of minor criminal cases from the perspective of restorative justice, settlement through penal mediation can be seen as an important thing to do and it is necessary to obtain a legal umbrella so that there is legal certainty in its implementation. Settlement of cases through penal mediation with a restorative justice perspective can be carried out by promoting deliberation that can bring together the perpetrator and the victim. By resolving the case by way of deliberation, this can be directed towards an agreement that satisfies both the perpetrator and the victim. Thus, the principle of forgiveness will also be put forward in the settlement of the case. In general, the urgency of implementing penal mediation in the criminal justice system in Indonesia, from the aspect of judicial administration is to reduce the accumulation of cases. The increase in the number of cases submitted to the courts at this time has resulted in an increasing burden on the court to settle cases within a limited time. However, it can be stated the urgency of the need for penal mediation in the settlement of minor criminal cases when viewed from the perspective of restorative justice, as follows: Because society dominates the development of the legal system. Community factors also influence the development and operation of the legal system. Law enforcement comes from society and has a close reciprocal relationship. Human relations in society also want the law to exist in a just manner. Talking about community factors means talking about the law in the social space. When talking about law in the social space, the enactment of law in society can also pay attention to the prevailing local wisdom, where in Indonesian society, a culture of peace / forgiveness has actually been widely 
applied as long as it does not have a very harmful effect on the public interest. The need to present modern laws to replace traditional laws. Law as accepted and implemented in Indonesia falls into the category of modern law. The presence of modern law makes law enforcement agencies no longer a place to seek justice (searching of justice), but as an institution that deals with rules and procedures. Justice has died dramatically in Law enforcement agencies under the modern legal regime. Furthermore, modern law not only causes very large and fundamental changes in the administration of law. The presence of modern law also often becomes a burden to the receiving community. Modern law makes itself something exoteric which ordinary people cannot simply enter and understand. The location of the tragedy of modern law, namely the law is further away from public justice. The solution cannot be done by the usual and conventional legal means. This progressive idea is expected to be able to help get out of the confines of legal methods that are considered standard. In relation to the law enforcement process, the formal (criminal) justice system, namely the police, judges, prosecutors and police, almost lack in-depth knowledge (even don't care) about the social problems of the victim, such as family background and livelihoods. The law enforcer only looks at the crime so that when handling and deciding cases, the social aspects of victims tend to be ignored. The work orientation towards results rather than process makes the judiciary more in pursuit of quantity, such as the number of cases handled and the speed of completion rather than considering the quality of decisions honestly and fairly.

Progressive law enforcement is carrying out the law not just according to the black and white words of the regulations (according to the letter), but according to the spirit and the deeper meaning (to the very meaning) of the law or law. Law enforcement is not only with intellectual intelligence but with spiritual intelligence. In other words, law enforcement is carried out with full determination, empathy, dedication, commitment to the suffering of the nation and accompanied by truth to find a way other than what is usually done. IV. CONCLUSSION AND SUGGESTION The implications of resolving criminal cases through restorative justice in Indonesia are at a restorative stage because victim involvement is not a major concern, decisions are made by parties who are not directly affected, and there is no choice of dialogue between directly affected parties, this is caused by the location of the focus is the violated legal rules and the consequences caused by the dressing and does not focus on restoring the damage or loss suffered. Stakeholders are the key to providing information to a limited level, some stakeholders have several decisions or inputs but the final decision is still approved by the formal system. Based on the above conclusions, the researcher recommends that the settlement of criminal cases through restorative justice in Indonesia has not been implemented in an integrated manner, this is because the subchapters of the criminal justice system, namely the police, prosecutors, judiciary, correctional institutions in Indonesia do not fully understand what exactly is happening. is meant by the concept of restorative justice. The concept or approach of restorative justice must be implemented by all sub-criminal justice systems in an integral, consistent and sustainable manner so as to create a restorative integrated criminal justice system. In the Indonesian criminal justice system, the provisions regarding disclosure are very strict and clearly regulated in the Criminal Procedure Code, which is derived from the principle of open court hearing to the public. Meanwhile, the model of the meeting (conference, meeting) of restorative justice is usually arranged privately (private setting), so the problem is how judges and legal advisors judge that the interests of each party are respected. Legal reform in Indonesia cannot be separated from the objective conditions of Indonesian society that uphold the values of religious law in addition to traditional law so that the suggestion in this study is that it is necessary to explore legal products that are rooted and rooted in cultural, moral and religious values.

\section{REFERENCES}

Achmad Ali. 2005. Keterpurukan Hukum di Indonesia. Bogor. Ghalia Indonesia.

Bambang Sunggono. 1997. Metodologi Penelitian Hukum. Jakarta. Raja Grafindo Persada.

JJ. Brugink. 1995. Rechtsreflecties. Alih bahasa oleh Arief Sidharta.

Johny Ibrahim. 2006. Teori dan Metode Penelitian Hukum Normatif. Malang. Bayumedia Publishing.

Natangsa Surbakti. 2012. Filsafat Hukum Perkembangan Pemikiran dan Relevansinya dengan Reformasi Hukum Indonesia. Surakarta. BP-FKIP UMS.

Peter Mahmud Marzuki. 2008. Penelitian Hukum.

Peter Mahmud Marzuki. 2008. Penelitian Hukum. Jakarta. Prenada Media.

Ronny Hanitijo Sumitro. 1989. Perspektif Sosial dalam Pemahaman Masalah-Masalah Hukum. Semarang : CV. Agung.

Satjipto Raharjo. 1996. Ilmu Hukum. Bandung. Citra Aditya.

Sidharta. 2010. Penelitian dalam Perspektif Normatif. Semarang. Makalah Seminar Nasional, Metodologi Penelitian dalam Ilmu Hukum. Oleh Bagian Hukum dan Masyarakat Fakultas Hukum Undip tanggal 16 Desember 2010.

Soerjono Soekanto dan Sri Mamuji. 1995. Penelitian Hukum Normatif Suatu Tinjauan Singkat.

Soerjono Soekanto. 1986. Pengantar Penelitian Hukum. Jakarta. UI Press. 
Sri Mamuji. 1997. Teknik Menganalisa Dokumen. Jakarta. Paper on Penataran Metode Penelitian Hukum, tanggal 21-31 Juli.

Sudikno Mertokusumo. 2009. Penemuan Hukum Sebuah Pengantar. Yogyakarta. Liberty.

Sugeng Istanto. 2007. Penelitian Hukum. Yogyakarta. CV. Ganda.

Teguh Praseto dan Abdul Hakim Barkatullah. 2009. Ilmu Hukum dan Filsafat Hukum Studi Pemikiran Ahli Hukum Sepanjang Zaman. Yogyakarta. Pustaka Pelajar.

Visser't Hooft. 2003. Filosofie Van de Rechtswesstenschapy, diterjemahkan oleh Arief Sidharta. Filsafat Ilmu Hukum. Bandung. Laboratorium Hukum Fakultas Hukum Universitas Parahyangan.

Yusriadi. 2009. Teebaran Pemikiran Kritis Hukum dan Masyarakat. Malang. Surya Pena Gemilang.

National Instruments

Undang-Undang Dasar Negara Republik Indonesia Tahun 1945

Undang Undang Republik Indonesia Nomor. 48 Tahun 2009, Kekuasaan Kehakiman,

Undang Undang Republik Indonesia Nomor 16 Tahun 2004, Kejaksaan

Undang-Undang Republik Indonesia Nomor 2 Tahun 2002 tentang Undang-Undang Kepolisian Negara Republik Kitab Undang-Undang Hukum Pidana

Kitab Undang-Undang Hukum Acara Pidana

Peraturan Mahkamah Agung Republik Indonesia Nomor 1 Tahun 2008 Tentang Prosedur Mediasi di Pengadilan menyatakan bahwa semua sengketa perdata yang diajukan ke Pengadilan

Undang-Undang Nomor 11 Tahun 2012 tentang Sistem Peradilan Pidana Anak

UU No 2 Tahun 2002

UU No. 23 Tahun 2004

UU No. 11 Tahun 2011 